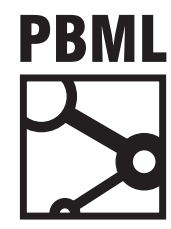

The Prague Bulletin of Mathematical Linguistics

NUMBER 106 OCTOBER $2016 \quad 21-30$

\title{
In favour of the Argument-Adjunct Distinction (from the Perspective of FGD)
}

\author{
Jarmila Panevová \\ Charles University, Faculty of Mathematics and Physics, Institute of Formal and Applied Linguistics
}

\begin{abstract}
In this article, the critical remarks of Adam Przepiórkowski concerning the ArgumentAdjunct distinction in Functional Generative Description printed in this issue are discussed and some counterarguments are given.
\end{abstract}

\section{Introduction}

In his article Against the Argument-Adjunct Distinction in Functional Generative Description (Przepiórkowski, 2016) printed in this issue, Adam Przepiórkowski (henceforth AP) presents his critical remarks on the theory of valency used in the Functional Generative Description (henceforth FGD). Any serious discussion on this topic poses a significant challenge to the author responsible for the discussed texts to check her own formulations and their background. I was stimulated to go back to my first attempt at coping with valency issues within FGD and to compare my "historical" and contemporary views with AP's opinion. My comments here are based on the conviction that linguistic research based on some defined criteria is better than research based on intuition and ad hoc classification. We do not expect, however, that all language phenomena fit into the boxes determined by any criteria because of the vagueness belonging to the language itself, because of unclear boundaries between ontological content and language meaning and other phenomena typical for natural languages (such as ellipsis, metaphoric meanings etc.). 


\section{Argument-Adjunct Distinction in FGD}

Let me start here with the last $\mathrm{AP}^{\prime}$ 's objection given at the end of his article (in Sect. 6), because there AP's alternative solution is proposed:- 1 He suggests that the discussed dichotomy between what he calls arguments (corresponding to the actants or inner participants and semantically obligatory adverbials in our current terminology) and adjuncts (corresponding to non-valency free adverbials or free modifications in our terminology) is not needed for FGD at all. Instead, he proposes to construct a "full-fledged lexicon" capturing all information about all possible dependents of a verb with all requirements and constraints for their application. This idea, however, has as its theoretical consequence in a shift of grammar (or at least its great part) to the lexicon. Restrictions such as incompatibility of temporal modifications with the meaning "how long" with perfective aspect of verb in Slavic languages (see e.g. AP's examples (14a), (14b), (14c) and (15a), (15b), (15c))2 are treated in FGD by the grammatical component similarly to other types of (non-valency) constraints (e.g. incompatibility of adverb yesterday with the future tense of its governing verb etc.). Many valency issues concerning the grammar-lexicon interface as the relation between valency members and their alternations or deletability on the surface due to aspect, diathesis, generalization, lexicalization etc. are discussed in the papers and books on valency and lexicon in FGD (Panevová, 2014; Panevová and Ševčíková, 2014; Lopatková et al., 2008 , e.g.). In addition, the lexicon proposed by AP will not satisfy the basic principle applied for the tectogrammatical level of FGD, namely to introduce as small number of elementary units as possible (quoted by AP from Sgall et al., 1986, p. 101), as it implies overloading the lexical entries with the information repeated many times with different lexical items.

AP considers the criteria used for the distinction between valency and non-valency members formulated for FGD in Panevová $(1974,1975)$ as ill-formed. He has in mind the criteria (1) and (2), quoted from Panevová (1974, p. 11) and slightly modified here by me as (I) and (II):

(I) Can the given modification depend on every verb? (AP calls this criterion with a contemporary term "specificity").

(II) Can the given modification be repeated with a single governor? (called "iterability" by AP).

Modifications which satisfy neither (I) nor (II) are classified as valency members in FGD and they are called inner participants (their governors need to be listed and they are not repeatable). $\underline{3}$ The rest of modifications which are positively classified

\footnotetext{
${ }^{1}$ In the continuation of my reply, I follow the structure of AP's article.

2 (14a) Janek tańczyl dwie godziny., (14c) *Janek zatańczyl dwie godziny. For a more detailed comment see Section $\underline{4}$ below.

${ }^{3}$ The special position of Actor is taken into consideration in both discussed texts (mine and AP's as well).
} 
according to (I) and (II) are called free adverbials and their free compatibility with any verb is assumed.

$\mathrm{AP}$ is right that for some types of modifications classified according to the criteria (I) and (II) as free adverbials, there are some "ontological" conditions blocking their compatibility with some semantic classes of verbs. Some types of unexpected combinations are illustrated and discussed in Panevová (1994, p. 227, examples (1)-(5) there), e.g. adverbial of purpose (AIM) connected with the verb of the change of state is illustrated by (1), the adverbial of instrument (MEANS) with unconscious event is illustrated by (2). On the other hand, the necessity for each verb to list a set of its inner participants called either Patient or Objective (or otherwise) seems to be obvious, because an omission of such dependents usually leads to ungrammaticality.

(1) John fell ill in order to be punished for his sins.

(2) He missed the target with two out of five arrows.

Though such combinations exemplified by (1) and (2) are rare, to exclude the possible combinations from the system in advance means to reduce the potentiality of the language system as a living organism.

Table 1 presented in Panevová (1978) and included by AP in Section 2 of his article followed by his critical remarks is really a bit misleading in the context of the basic criteria for the determination of valency and non-valency dependents. Actually, the table was motivated by my considerations about granularity vs. unity within the set of dependents and it was inspired by Fillmore's (1971) notion of "hypercase" and "crossed brackets" which I "played down" later. . Instead of the table a simpler scheme was used:

\begin{tabular}{lcc} 
& Obligatory & Optional \\
\hline Inner participant & + & + \\
Free adverbial & + & -
\end{tabular}

This scheme representing the structure of the verbal valency frame indicates that the class of modifications determined as inner participants always enter the valency frame as an obligatory or optional part of it (marked +$),-\frac{5}{-}$ while adverbials are included in the valency frame only if they were determined as (semantically) obligatory. -

\section{Iterability}

As for the criterion (II), iterability, AP is right that it is not quite easy to find natural examples of repeating or splitting some types of modifications.

\footnotetext{
${ }^{4}$ The same motivation is behind considerations in Panevová 1977, p. 55f and Panevová 1978, p. $243 \mathrm{ff}$.

${ }^{5}$ According to the results of our empirical studies Actor, Patient, Addressee, Origin, and Effect belong to inner participants.

${ }^{6}$ Free adverbials belong to the valency frame either if the sentence is grammatically incorrect without them ( Jan směruje ["John aimed]) or if - in case of their absence on the surface - the "dialogue" test supports their semantic obligatoriness (see Section $\underline{5}$ below).
} 
However, if I understand the author well, he admits the iterability of such modifications which refer to the same entity. He supports this view by Bresnan's and Goldberg's examples quoted by him as (3), (5) and (6) with multiple occurrence of modifications of the same type. AP demonstrates the ungrammaticality of two instruments (MEANS) referring to the different entities by Bresnan's sentence quoted as (4). Our examples (3) and (4) below $\underline{7}$ with two instruments (MEANS) referring to the different entities could be understood as counterexamples to Bresnan's (and AP's?) view.

(3) Jan napsal gratulaci matce poraněnou levou rukou perem.

'John wrote the congratulation to his mother by his injured left hand by the pen.'

(4) Silnici opravili pomocí těžkých strojů štěrkem a pískem.

'They repaired the road with the help of heavy machines by gravel and sand.'

In Panevová (1974, p. 15), we have presented also examples with iterated cause and iterated condition without reference to the identical entity or event.

In our approach the issue of iterability of dependents is not influenced by their identical or different reference; according to our view, such aspects are related to the layer of the cognitive content. With regard to the language structure three locatives and one apposition relation are present in the ex. (5):

(5) V Praze, hlavním městě České republiky, bydlí Jan na Vyšehradě v malém bytě.

'In Prague, the capital of the Czech Republic, John lives at Vyšehrad in a small flat.'

The idea about iterativity of free modifications and the variety of examples supporting it in the quoted papers on FGD illustrate again the power of the language as a recursive system with potential infiniteness.

AP's examples (7) (with its modifications (8), (9), (10)) and ex. (11) which should document the iterability of inner participants could be hardly interpreted as the repetition of Patient (Objective or so) and Subject (Actor), respectively. The necessity of separation of the two parts of the supposed "iteration of the inner participant" by a comma for the "second occurrence of the participant" is sufficient for a hesitation about their status. AP admits that they could be classified as appositions. $\frac{8}{-}$ Moreover, one can doubt about acceptability of (11) with splitted "apposition". 9 Thus we still believe that iterability of inner participants is not possible.

\footnotetext{
7 According to AP's opinion (in his Footnote 4) the dependent in my Russian example na rojale 'on piano' is a "core argument" of the verb igrat' 'to play' instead of Instrument as it is presented in Panevová (2003). In both Czech valency lexicons VALLEX (Lopatková et al., 2008) and PDT-Vallex (Urešová, 2011) the verbal frame of the corresponding meaning of hrát 'to play' has an optional accusative PAT and the dependent expressed as na + Local is characterized as a free adverbial with functor of MEANS ( $h r a ́ l ~ t u ~ s k l a d b u$ (na piano)) 'he played this composition (on the piano)'.

${ }^{8}$ Apposition is a different type of syntactic relation than dependency, the core of our discussion here.

${ }^{9}$ See an analogy given by Eyende Van and Kim (2016): "Separating the appositions from the anchor, as in (5b), yields an ill-formed result:" (5a) Sarajevo, the capital of neighboring Bosnia, is where the World
} 


\section{Specificity}

AP presents McConnell-Ginet's (1982) examples to illustrate the limitation of free compatibility of the verb to weigh with "many typical adverbials" which he quotes as examples (12) and (13). However, many typical or untypical adverbials modifying this verb could be given, see (ㅁ), (ㅁ):

(6) Annie weighs surprisingly/obviously 120 pounds.

(7) Annie weighed 120 pounds in the last year/for the last 5 years/to her mother's disappointment/at hospital/in Detroit.

As for the position of aspectual pairs in Slavonic languages, this issue has been discussed in linguistics for several last decades. In FGD the aspectual pairs are understood as a single lexeme (represented by different verb lemmas distinguished with a different morphological features), see Panevová et al. (1971, p. 28ff), Sgall et al. (1986, p. 165), Lopatková et al. (2008, p. 14). The choice of the appropriate form of the temporal modifier with regard to the aspectual meaning of the verb is treated in the grammatical component of FGD. It concerns the compatibility of the verb with the functors "how long" and "for how long", $\underline{10}$ as well as the possibility to omit a Patient (Objective) with the imperfective aspect of particular classes of verbs and its obligatory occurrence with the perfective aspect (e.g. psát/napsat [to write], číst/přčcist [to read], počítat/spočitat [to count] etc.). 11

\section{Semantic obligatoriness}

AP puts under scrutiny the "dialogue" test used to determine whether a particular modification is (semantically) obligatory for a tested lexical item. This test was proposed as a tool for the decision about whether a modification absent in the surface form of a grammatically correct sentence is obligatory or not from the point of view of the deep (tectogrammatical) structure. According to the opinion of the users of this test (e.g. the authors of valency dictionaries, $\underline{\underline{12}}$ annotators etc.), some doubts about acceptability of the answer "I don't know" occur especially in cases where the tested modification could be "generalized" in the given context. $\underline{13}$

War began.

(5b) *Sarajevo is where the World War began, the capital of neighboring Bosnia.

10 These two meanings are understood as contextual variants of a single functor in Panevová et al. (1971, p. 75). In the Prague Dependency Treebank, the solution to introduce them as two different functors was applied, see Mikulová et al. (2006, p. 484).

${ }^{11}$ Czech and Polish probably differ as to possibilities of the omission of object: the presence of object is required in Czech counterparts of AP's ex. (14b) and (14c).

${ }^{12}$ Lopatková et al. (2008), Urešová (2011).

${ }^{13}$ The notion of generalization of participants is analyzed esp. in Panevová (2001, 2004). See below, e.g. ex. (9). 
$\mathrm{AP}$ is right that in this sense the dialogue test has common features with Fillmore's approach and with his examples (quoted by AP in his article as (16), (17), (18)) illustrating the presence of the "indefinite implicit argument". I have discussed Fillmore's examples recalled by AP in this context in Panevová (1994, ex. (14)-(18), my example (14) is repeated here as (ㅇ)).

(8) a. John bought a dozen roses. $\underline{14}$

b. John paid Harry five dollars.

Fillmore (1977, Section 5) considers two possible solutions:

"one typical way of dealing with conceptually obligatory but superficially optional elements in a sentence is to claim that these elements are present in the deep structure but deleted or given zero representation on the surface structure",

but he prefers the solution

"to say that a word like buy or pay activates the commercial event"

[containing money and buyer articulated in (8)b. - JP], however

"it may not be necessary to believe that everything that is included in our understanding of the sentence [the whole commercial scene in this case - JP] is necessarily a part of underlying grammatical structure of the sentence".

The users of our dialogue test face the same problems formulated in the quoted part of Fillmore's paper: What is the "complete scene" and which part of it must be reflected in the underlying sentence structure (and therefore included in the valency frame).

In Panevová (2001, Section 2) and in Panevová (2014, Section 4), several experimental dialogues were construed in order to use the dialogue test in an attempt to determine the boundaries of "generalized" semantically obligatory valency members (on the one hand) and semantically optional participants and non-valency free adverbials (on the other hand). Some of them are illustrated by (9), (10) and (11) below:

(9) a. Sue sells at Bata store.

b. What does she sell?

c. To whom does she sell?

The answer "I don't know" given by the speaker of (aㅡ) after (9b) and (9c) is not appropriate, though he/she can list neither the sold objects nor the set of buyers. A more appropriate response to these odd questions would sound like (9d) and (9e), respectively; it indicates the obligatory but generalized valency slots (Patient and A ddressee) for the verb to sell with this lexical meaning. Further difficulties for the testing are caused by the polysemy of lexical units. In (9), we have to do with the meaning "to

\footnotetext{
14 Ex. (14) in Panevová (1994) repeated here as (8) corresponds to Fillmore's (1977) ex. (12a), quoted now from the reprinted version 2003, p.192). John is used instead of I as the identity of the speaker with the Actor is not suitable for testing by the proposed dialogue test.
} 
be a shop-assistant", while in (10) a usual transfer action of an object is presupposed. In the latter meaning the Addressee (buyer) seems to be an optional participant:

(9) d. She sells goods typical for Bata stores (shoes, bags etc.)

e. She sells to the typical customers of the shop.

(10) a. John finally got rid of his old car, he sold it.

b. To whom?

c. I don't know (who the buyer was).

In ex. (11a) there is a complete scene for the verb to speak, Addressee and Patient are expressed. However, the question (11d) addressing (11b) could be naturally answered "I don't know", it indicates that for the Czech verb mluvit [to speak] the Patient is an optional rather than an obligatory participant, while the question (11e) addressing (11d) hardly could be answered "I don't know", but rather "with the listeners present there", which is the formulation typical of generalized members.

(11) a. John spoke with his teacher about the good-bye party.

b. I saw John in the corridor as he spoke with his teacher.

c. John spoke in the corridor about his leaving for the USA.

d. What did they speak about?

e. With whom did John speak?

These dialogues, if they are accepted as well-articulated dialogue tests, support a valency frame with an obligatory Addressee and an optional Patient for the verb mluvit [to speak] with the given meaning (corresponding to the meaning 1 in VALLEX).

As to the verb to rain, I can imagine a simpler context for AP's ex. (23) quoting Racanati's considerations:

(12) A: There will be a lot of mushrooms this year, because it was raining.

$\mathrm{B}$ : Where was it raining?

A: I don't know (exactly), everywhere. $\frac{15}{}$

AP is right that the idea to use the dialogue test for identifying valency was inspired by the article Sgall and Hajičová (1970) where a set of possible questions related to the sentence tested by them He wrote all these books. is proposed. Actually, this set of questions was presented there in order to test relationships between form, meaning and content. However, one of the questions formulated there was for me more stimulating for the application to Slavonic languages exhibting the pro-drop character: The Czech example (13) justifies more transparently the application of the dialogue test for the purposes of testing obligatoriness. The odd feeling of the dialogue in (13) is obvious:

\footnotetext{
${ }^{15}$ In both valency dictionaries (VALLEX and PDT-Vallex) the verb pršet [to rain] has an empty frame (i.e. it has no valency dependents). I am not sure whether the reply "everywhere" in dialogue test is equivalent for the notion of generalized complement rather than for a reply "I don't know". However, the question B in (12) sounds really odd, if B does not ask for adding of specific information (which is excluded from the dialogue test, see Panevová (1978, p. 229)).
} 
(13) a. Včera už Marii knihu vrátil.

[Yesterday (he) already gave the book back to Mary.]

b. Kdo ji Marii/jí vrátil? [Who did give it back?]

c. $\quad$ Nevím [* I don't know.]

During the long period of its application the dialogue test, described in many papers and used for compilation of valency dictionaries, appeared to work well for most cases. In problematic cases the result depends on particular users - as Fillmore says - on his/her particular knowledge of the scene.

\section{Does FGD need AAD?}

According to AP the dichotomy valency vs non-valency dependents does not play any role in the formalism of FGD with a single exception included in the definitions of obligatory expansion rules during the sentence generation. However, the application of these rules for a particular verb is one of the crucial prerequisites to generating grammatically correct outputs. $\frac{16}{}$ AP correctly states that "no contentful reference to this dichotomy (i.e. argument - adjunct, $J P$ )" is made in the discussion of systemic ordering relevant to the word order of verbal dependents in (Sgall et al., 1986, Chapter 3, pp. 198-199). However, this fact cannot serve as a counterargument to the given dichotomy. It means that the dichotomy simply concerns an aspect of the sentence structure independent of communicative function. In the specification of the systemic ordering the labels of the functors are used as notions defined in the Chapter 2 of the quoted monograph.

Summarizing the approach used for FGD I believe that:

- By the application of criteria (I) and (II) from Section 2, we have provided a classification of the proposed list of semantic units (functors) into two classes: inner participants and free adverbials.

- The dialogue test proposed as a tool for constituting valency frames in the cases of surface absence of a position pretending to be included in the valency frame makes it possible to distinguish between semantically obligatory and optional modifications. The issue (I) reflects a paradigmatic dimension for the list of possible modifications, while with (II) a syntagmatic dimension (verb + its dependents) is taken into account.

We have tried to present here a realistic view on the criteria (I) and (II) and on the dialogue test, admitting some empirical difficulties connected with different pragmatic attitudes of specific speakers. However, first of all we want to defend the necessity of the argument (valency dependent) and adjunct (non-valency dependent)

\footnotetext{
16 Thus the expansion of the verb by an obligatory PAT is stated once in the basic component generating tectogrammatical representations, the lexical data (which verbs are concerned) being extracted from the lexicon.
} 
dichotomy for the theoretical framework based on the cooperation of two modules: lexicon and grammar.

\section{Acknowledgements}

The work on this paper was supported by the project GA ČR 16-02196S “Valenční slovník českých substantiv založený na korpusu".

\section{Bibliography}

Eyende Van, F. and J. B. Kim. Loose Apposition. Functions of Languge, 23(1):17-39, 2016.

Fillmore, C. J. Some Problems for Case Grammar. In O'Brien, R. J., editor, 22nd annual round table. Linguistics: Development of the sixties - viewpoints of the seventies, volume 24, pages 35-56. Georgetown University Press, Washington, D. C., 1971.

Fillmore, C. J. The Case for Case Reopened. In Cole, P. and J. M. Sadick, editors, Syntax and Semantics, Grammatical Relations 8, pages 59-81. Academic Press, New York - San Francisco - London, 1977.

Lopatková, Markéta, Zdeněk Žabokrtský, and Václava Kettnerová. Valenční slovník českých sloves. Nakladatelství Karolinum, Praha, 2008. ISBN 978-80-246-1467-0.

McConnell-Ginet, Sally. Adverbs and Logical Form: A Linguistically Realistic Theory. Language, 58(1):144-184, 1982.

Mikulová, Marie, Alevtina Bémová, Jan Hajič, Eva Hajičová, Jiří Havelka, Veronika Kolářová, Lucie Kučová, Markéta Lopatková, Petr Pajas, Jarmila Panevová, Magda Razímová, Petr Sgall, Jan Štěpánek, Zdeňka Urešová, Kateřina Veselá, and Zdeněk Žabokrtský. Annotation on the tectogrammatical level in the Prague Dependency Treebank. Annotation manual. Technical Report 30, Prague, Czech Rep., 2006.

Panevová, Jarmila. Verbal frames in Functional Generative Description. Part 1. The Prague Bulletin of Mathematical Linguistics, 22:3-40, 1974.

Panevová, Jarmila. Verbal frames in Functional Generative Description. Part 2. The Prague Bulletin of Mathematical Linguistics, 23:17-52, 1975.

Panevová, Jarmila. Verbal Frames Revisited. The Prague Bulletin of Mathematical Linguistics, 28: 55-72, 1977.

Panevová, Jarmila. Inner Participants and Free Adverbials. Prague Studies in Mathematical Linguistics, 6:227-254, 1978.

Panevová, Jarmila. Valency Frames and the Meaning of the Sentence. In Luelsdorff, Ph. L., editor, The Prague School of Structural and Functional Linguistics, pages 223-243. Benjamins Publ. House, Amsterdam-Philadelphia, 1994.

Panevová, Jarmila. Valency Frames: Extension and Re-examination. In Chrakovskij, Viktor S., Maciej Grochowski, and Gerd Hentschel, editors, Studies on the Syntax and Semantics of Slavonic Languages. Papers in Honour of Andrzej Bogusławski on the Occasion of his 70th Birthday, pages 325-340. BIS, Oldenburg, 2001. 
Panevová, Jarmila. Some Issues of Syntax and Semantics of Verbal Modifications. In Proceedings of MTT 2003 - First International Conference on Meaning-Text Theory, 2003. http: //meaningtext. net/mtt2003/proceedings/13. Panevova.pdf.

Panevová, Jarmila. Všeobecné aktanty očima Pražského závislostního korpusu (PZK). In Korpus jako zdroj dat o češtině. Sborník konference ve Šlapanicích, 2004.

Panevová, Jarmila. Contribution of Valency to the Analysis of Language, chapter 1, pages 1-18. Studies in Language Companion Series, 158. John Benjamins Publishing Company, Amsterdam, The Netherlands, 2014. ISBN 9789027259233.

Panevová, Jarmila and Magda Ševčíková. Delimitation of information between grammatical rules and lexicon, volume 215 of Linguistik Aktuell / Linguistics Today, pages 33-52. John Benjamins Publishing Company, Amsterdam, The Netherland, 2014. ISBN 978-90-272-5598-3.

Panevová, Jarmila, Eva Benešová, and Petr Sgall. Čas a modalita v češtině. Univ. Karlova, 1971.

Przepiórkowski, Adam. Against the Argument-Adjunct Distinction in Functional Generative Description. The Prague Bulletin of Mathematical Linguistics, 106:5-20, 2016.

Sgall, Petr and Eva Hajičová. A "Functional" Generative Description. The Prague Bulletin of Mathematical Linguistics, 14:9-37, 1970.

Sgall, Petr, Eva Hajičová, and Jarmila Panevová. The Meaning of the Sentence in Its Semantic and Pragmatic Aspects. Reidel, Dordrecht, 1986.

Urešová, Zdeňka. Valenční slovník Pražského závislostního (PDT-Vallex). Ústav formální a aplikované lingvistiky, Prague, 2011.

\section{Address for correspondence:}

Jarmila Panevová

panevova@ufal.mff.cuni.cz

Institute of Formal and Applied Linguistics

Faculty of Mathematics and Physics, Charles University

Malostranské náměstí 25

11800 Praha 1, Czech Republic 